\title{
Teachers Readiness in Facing Linear Learning in the Pandemic Covid-19 and the New Normal Era
}

\author{
I Gede Sudirtha*, Ni Ketut Widiartini \\ Research and Educational Evaluation Department \\ Universitas Pendidikan Ganesha \\ Singaraja, Bali, Indonesia \\ *gede.sudirtha@undiksha.ac.id, ketut.widiartini@undiksha.ac.id
}

\begin{abstract}
This study was made based on the analysis of several reports and survey results conducted during the Covid-19 pandemic which were obtained from reliable sources. Furthermore, the results of the report are analyzed and interpreted and some possible solutions are sought by educators in implementing learning during a pandemic, and the continuity of online learning if this pandemic period ends.
\end{abstract}

Keywords—online learning, education, teacher readiness

\section{INTRODUCTION}

Educators are a very strategic component in an education system. To achieve educational goals as expected, the teacher component must be ready to face all situations that occur in the education system. Education as a system needs to change, especially in relation to the quality and needs of human resources in this century [1]. Education is one of the institutions known to be the most difficult to change in the face of disruption [2].

However, if the conditions and methods of learning today are not much different from those of a century ago, education will be something very worrying when we prove that our education has been hit by three waves of disruption. From the perspective of students, disruption comes from millennial whose learning behavior is completely different from the previous generation. This change in behavior demands a radical change in the approach to education [3]. The fact that affects showing that very radical changes have occurred and will occur in the world of education today [4]. If the previous education took place in the context of a traditional education system where learning resources were real and with the presence of educators in the midst of students with very intense interactions, soon all of that would be disrupted by the circumstances and technological advances that would replace them. If education based on the description above will emerge, then what is the teacher's job? Will education take place without a teacher? Or is the teacher just silent? In our current education system, the teacher is a figure full of ideas to regulate the course of education and learning. At least the educators still have hopes and descriptions of this matter. There is a view that explains that the teacher is a great, meritorious figure, even a hero who is often called an unsung hero. With this predicate, the teacher is a great figure who will never lose his instinct, his adrenaline to educate and raise education [5].

The Great Teacher is the name for teachers who are able to make themselves, a figure whose remains in the hearts of their students, not a figure who is only present in front of their students (in the eyes of students). Surely the Great Teacher is a teacher who is able to maintain his existence as a great educator, his experience is his soul, his presence is his strength, and his figure is the protector of his students. This figure is a multi- talented educator, a figure who never loses his mind in carrying out his noble duties. They are able to teach their students in any situation, manage their class well in all obstacles and limitations, are still able to supervise their students in order to maintain their learning motivation in all forms of learning modes, and still focus on the character development of their students, and still care about their students' future [6].

Several research results in the field of education stated that the effectiveness of learning with the use of the surrounding environment has a positive impact on learning styles and to develop the ability to understand concepts in learning in elementary schools. Students are able to actualize their abilities so that they can interact well in the cognitive and psychomotor domains and meaningful learning occurs and increases student learning outcomes [7]. In developing instructional designs educators always strive for effective learning conditions to provide optimal service and learning outcomes. This study recommends that educators make use of the personal characteristics of identified learners to compile instructional designs, including several other factors in an effort to improve the quality of the learning process and the quality of learning outcomes [8,9].

From the aforementioned explanation, basically teachers/ educators will always strive for the continuity of an effective and quality learning process. Professional teachers have the ability to strive for their students to learn well to achieve their goals. However, in the context of learning in the midst of advances in information and communication technology in the industrial era 4.0, it is felt to encourage and disrupt learning at 
all levels of education, especially in the midst of physical distancing pressures that force all educational components to do online learning. For this reason, this study was carried out in order to identify and provide a view of the readiness of teachers in implementing online learning. This study will try to bring up some learning problems that arise from ongoing observations during physical distancing during the Covid-19 pandemic and during the new normal period.

Talking about learning, there are many factors that influence learning to occur. But basically, there are two general factors that affect learning to happen well, namely factors that come from internal students and factors that come from external students. Both of these factors are the driving force or motivation that becomes the learning power of students that arises through deliberately created interactions so that the motivation and potential of students can develop according to expectations. There is a very different concept that occurred at the time of this technological disruption. With the Covid-19 pandemic there are still no signs that all of us can meet face-toface as has been done in schools where interactions occur naturally without obstacles in the educational process. Teachers can take advantage of classes with various conditions, social climates, and cultures they have for the learning and education process. If seen from the picture below, the relationship between the components of education and learning in a natural atmosphere, interaction occurs ideally by placing educators as a very strategic component in managing the occurrence of educational interactions between students and other components. The relationship between these components can be illustrated in Fig. 1.

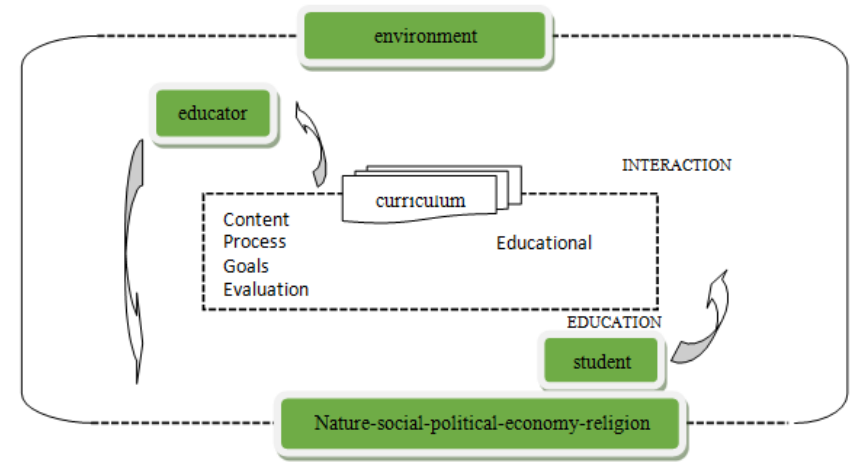

Fig. 1. Linkages between components in the education system.

During the Covid-19 pandemic, many learning and educational problems can occur. Problems arise from various sides of the weakness and unpreparedness of students, teachers and other components in seeking educational interactions. The curriculum that has been designed, the learning method, the well-planned approach suddenly has to change at once. Disharmony of interactions occurs due to the implementation of physical distancing which hampers many ideal interactions in the education and learning process. Students such as losing motivation in learning, moments of togetherness in class in an atmosphere of joy, the desire to meet their idol teacher, colleagues in a pleasant atmosphere seem to run aground by the situation. The content, process, and evaluation model which was originally carried out in an authentic way in terms of all forms of interaction and development of learning outcomes must also change. Educators are very busy making changes from face-to-face to online meetings. This is where the problem arises when there is no careful planning. Additionally, instructional goals and educational goals as much as possible must be achieved according to the demands of the curriculum and the national education goals.

Learning in network mode and offline mode should be carried out equally in achieving curriculum goals and educational goals. In the context of online learning by utilizing existing technological advances and the availability of learning platforms that are freely available, free of charge, or paid for, it should be utilized in this condition. Educators have the obligation to package educational interactions by including natural, social, cultural, and so on in a meaningful learning atmosphere in a curriculum through the content of learning materials, meaningful processes, and conducting authentic evaluations to achieve learning goals in an online mode. Educators as soon as possible change the conditions of learning and educators who were originally packaged in offline mode learning into online mode. This happened all at once in the midst of difficult conditions.

Psychologically, the teacher finds it difficult to make changes immediately. Many teachers are not ready for that. Likewise, students are not used to learning online. Parents who used to trust their education to schools are suddenly demanded to be friends with their children all day long at home. In fact, not a few parents become dizzy on their own in guiding their children to study at home and finally stress and become angry in situations like this. This is where many of the essence of education must be studied, interpreted, and even must be determined in a value how education and learning should take place and in what kind of atmosphere. On the other hand, some students accept the current learning conditions. On average, they have very high learning independence and have abilities that are above average.

\section{METHODS}

Our study was the literature review method consisting several steps: (a) Identifying the review focus, (b) Searching and mapping the available evidence, (c) Specifying the review question, (d) Identifying studies to include the review, (e) Data extraction and study quality appraisal, (f) Synthesizing findings to draw meaningful conclusion, and (g) Reporting the results for dissemination.

\section{RESULTS AND DISCUSSION}

Learning using online mode during the Covid-19 pandemic is a necessity. This condition cannot be denied or underestimated. However, like it or not, online mode learning must work in any condition, both during the pandemic and post-pandemic times. Based on the findings of monitoring and evaluation results on online learning even semester 2019/2020 
at the Faculty of Engineering and Vocational, Ganesha University of Education for students in the 2nd, 4th and 6th semester, totaling 609 students from 9 study programs (Informatics Engineering Education, Electrical Engineering Education, Mechanical Engineering Education, Information Management, Electronic Engineering, Computer Science, Information Systems, Family Welfare Education, and Culinary Arts Vocational Education). Several findings were obtained: (1) the implementation of online learning has been carried out since the issuance of the Chancellor's Circular on March 16, 2020 .

Several obstacles in the implementation of online learning include signal quality, which is limited internet quota. Signal quality is still not good enough in some areas so that it becomes an obstacle to obstruct the implementation of online learning. (2) from the learning planning aspect, the findings were: online learning planning, $12 \%$ stated that it was unclear; The alignment with the learning objectives that have been designed, as many as $31 \%$ stated that it was unclear and (3) providing online implementation instructions before lectures started was still not good (37\%). (3) In the delivery aspect, it was found: the quality of the content/ material delivered through online learning, it was found that $19 \%$ stated it was not good; the quality of the various objects as much as $31 \%$ stated that they were not good; the quality of the presentation design was $13 \%$ less good; (4) $6 \%$ of learning initiation timeliness was found to be not good, $13 \%$ stated that it was not good when online learning activities ended. (4) In the aspect of interaction, the findings were: ease of accessing online learning services, $12 \%$ stated that it was not good, the quality of giving comments by lecturers to academic discussion forums that had been carried out in online learning, it was found that $6 \%$ said it was not good. (5) In the evaluation aspect, the following findings were obtained: the clarity of the assessment rubric of the assignment given by the lecturer, it was obtained that $12 \%$ stated that it was unclear, the scoring service for the assignment that had been given by the lecturer to students through online was $6 \%$ less well [10].

Quoted from the page https //: edukasi.kompas.com, 2020, related to the experience of students learning from home during the Covid-19 pandemic, UNICEF conducted a survey on 18-29 May 2020 and 5-8 June 2020. With more than 4,000 responses of students in 34 provinces of Indonesia, the survey results said that as many as $66 \%$ of the 60 million students from various levels of education in 34 provinces admitted that they were uncomfortable studying at home during the Covid-19 pandemic. Of these, $87 \%$ of students want to return to school immediately, $88 \%$ of students are also willing to wear masks at school and $90 \%$ say the importance of physical distance if they continue learning in class. Even so, students have realized the impact of Covid-19 if they return to school. It is stated that it is not without reason that students feel uncomfortable when they have to study from home rather than at school. Furthermore, these findings also show that while studying at home, $38 \%$ of students who became respondents said that lack of guidance from teachers was the main obstacle. Meanwhile 35\% cited poor internet access.
Another finding that is no less important is that if online learning continues, more than $62 \%$ of respondents said internet quota was needed. Furthermore, from the page https //: Muda.kompas.id, 2020, mentions the same thing, namely; As many as $97.5 \%$ of the 121 respondents stated that during the Covid-19 pandemic, learning was carried out in an online mode, the rest said they did not know and some stated that learning was still taking place semi online. The use of websites such as quizzes, gfroam, etc., in online learning, is said to place the highest position compared to other learning platforms. If the Covid- 19 pandemic would end, many of them still really want the online learning model to be applied in schools and colleges.

Some of them stated that they did not agree with the online model for reasons as mentioned above. Besides, there are also those who say that online learning is not very effective because they are not used to using this mode. Some of the responses obtained from the UNICEF survey results above include UNICEF's representative in Indonesia. Debora said it was very important for the government to prioritize children's learning, both at school or at distance during the Covid-19 pandemic. Furthermore, it was stated that children were the most vulnerable in facing this kind of condition. They have been hardest hit by school closings and we know from the previous crisis that the longer they are not in school, the less likely they are to return to school. In line with this response, UNICEF Education specialist, Warman, added that parents and students who were respondents said the biggest obstacle students faced when learning from home was the lack of internet access and supporting electronic devices. Parents should also focus on other obligations to support their family. Parents do not have time to help their children [11].

Several problems in the Covid-19 pandemic that are experienced globally require very serious handling. The components of the education system in this case are educators and students who have been very hard hit by this condition. They must be assisted and cared for in their efforts to revive learning through different modes of learning and change suddenly from previous normal conditions. Educators and parents must have an understanding that is in tune with the current conditions. Parents as study friends at home and educators must try to rebuild students' self-confidence. Teachers as the great teachers always strive for the best for their students in all conditions. Teachers will never run out of wits in managing learning. Teachers always find solutions in overcoming learning problems. This kind of belief is a reflection of the figure of the great teacher that has been inherent in the teacher / educator. In this case, a great teacher who has assumed the teaching profession should no longer have a problem with whether the learning takes place in networked or online mode. In the concept of the treat teacher, educators will never run out of reason in implementing learning for their students. This is in line with the concept of learning from B.F. Skinner (1958), which states that learning is a process of adaptation or behavior adjustment that takes place progressively [12]. In this context, students must be supported by all components of education, including educators, as a 
strategic component, always striving that change always makes educators and teachers a progressive learner and learner component, always adapting to all changes for the better.

Regarding the problems faced by teachers in pursuing progressive learning, educators make improvements through increasing their abilities in various things such as; increasing ability in the field of using technology in learning, especially in the field of information technology or implementing technology into learning technology as recommended in several research results and development of learning media based on augmented reality, virtual reality. Furthermore, educational educators and researchers always seek and produce findings in the field of education and learning that lead to solving or helping learning problems in current conditions. Learning in this network is believed to continue and is part of the learning model that is the trend today and even in the future. This belief is also in accordance with the development and advancement of technology in the industrial revolution 4.0 towards society 5.0 with its various characteristics.

Likewise, the assessment activities carried out in online learning mode. Learning planning is a concept of how learning will be implemented, then how to assess authentic learning, and how to follow up on the results of the assessment. This is also emphasized by Anderson and Krathwohl stated that the mismatch between objectives, learning and assessment can cause problems. For example, if learning is not in accordance with the assessment, high-quality learning will not be beneficial for students in carrying out the assessment. In this context, the problem of learning and its relation to the use of appropriate assessment needs to be revised or adjusted to the conditions of learning online. Whether the assessment carried out as part of learning is in accordance with the direction, activity, and learning objectives designed. This is always part of the analysis of learning by the teacher, because the three things above are a complete and interrelated whole. The focus of problems in the field of assessment also needs to be studied and adjusted by educators in changing learning conditions. Such as the use of the quizizz application, google form, or a developed application-based assessment form that is in accordance with the nature of education and learning through research and development [13].

In the context of economic, social, and cultural problems that were also affected during this pandemic, it is also an issue that needs to be found in the context of our learning. Educators are at the forefront of human resource development. So progressively education must also be able to unravel and find solutions to current economic, social, and cultural problems. This is in accordance with the demands of learning competencies in the $21 \mathrm{st}$ century such as mastery of $4 \mathrm{c}$ competencies (critical thinking, creative and innovative, communication, collaborative). If a number of problems arise today as national and global problems, according to the recommendation of Harvard Kennedy School which states that in 2025, even though Indonesia's economic growth can continue, Indonesia will experience shortages in three basic things, such as; (1) job creation. Indonesia is not fast enough to create many jobs for a growing workforce. What happens is jobless growth, (2) competitiveness. Indonesia will not be diverse, productive, or economically integrated enough to continue. What happens is a decrease in competitiveness (declining competitiveness), (3) gaps. Indonesia will not be fair and equitable enough in terms of the prosperity of its national wealth. What happens is an increase in inequality (rising inequality). In responding to this recommendation, our education must be able to make this criticism a big challenge for our world of education. How education can contribute to sowing this problem so that a solution can be found.

\section{CONCLUSION}

From some of the findings and discussion above, several conclusions are conveyed: (1) it is impossible to deny the change in learning modes as a learning mode that is trending, even as a solution in facing the current era of disruption, as well as during the Covid-19 pandemic; (2) educators must realize that the change in the learning paradigm that was previously only sourced from nature, naturally leads to learning resources created through a combination of digital technology and real nature and other forms of technology that can be accommodated in learning; (3) educators bearing the great Teacher will always strive and make sure that learning continues well in achieving learning objectives through various efforts.

\section{REFERENCES}

[1] P.S. Muljana, P.M. Nissenson, and T. Luo, "Examining Factors Influencing Faculty Buy-in and Involvement in the Accreditation Process: a Cause Analysis Grounded in Systems Thinking," TechTrends, vol. 64, pp. 730-739, 2020.

[2] Yuswohady, "Nadiem dan Disrupsi Pendidikan Kita," 2019. [Online] retrieved from: https://www.yuswohady.com/2019/10/25/ (accessed Aug. 18, 2020).

[3] J.D. Holst, "Challenging Neoliberalism Through Radical Adult Education in a Chilean Union School," Adult Educ. Q., vol. 71, pp. 1$17,2020$.

[4] J. Lin, "From a lecturer to a researcher: a threestage process of science teachers' professional development in mainland China," Asia-Pacific Sci. Educ., vol. 5, pp. 5-11, 2019

[5] K. Kolomitro, L.W. MacKenzie, D. Wiercigroch, and L. Godden, "The Design and Evaluation of a Master of Science Program in Anatomical Sciences at Queen's University Canada," Anat. Sci. Educ., vol. 11, pp. 613-622, 2018.

[6] M.W. Kier and M.R. Blanchard, "Eliciting Students' Voices Through STEM Career Explorations,” Int. J. Sci. Math. Educ., pp. 1-19, 2020

[7] N.K. Bintarini, A.A.IN. Marhaeni, and I.W. Lasmawan, "Determinas Pemanfaatan Lingkungan Sekitar Sekolah Sebagai Sumber Belajar Terhadap Gaya Belajar Dan Pemahaman Konsep IPS Pada Siswa Kelas IV SDN Gugus Yudistira Kecamatan Negara," e-Journal Progr Pascasarj. Univ. Pendidik. Ganesha Jur. Pendidik. Dasar, vol. 3, no. 1, pp. 1-11, 2013

[8] R.P.N. Puji and A.R. Ahmad, "Gaya Belajar dan Kemahiran Pemikiran Sejarah dalam Pembelajaran Sejarah di Peringkat Universitas," Edusentris, J. Ilmu Pendidik. dan Pengajaran, vol. 2, no. 3, pp. 253-263, 2015. 
[9] J. Popay, "Guidance on the conduct of narrative synthesis in systematic reviews," in A product from the ESRC Methods Programme, 1st ed., United Kingdom: Lancaster University, 2006, pp. 1-92.

[10] GKM FTK Undiksha, Laporan Hasil Monitoring dan valuasi Pembelajaran Daring tahun ajaran 2019/2020. Singaraja: GKM FTK Undiksha, 2020.

[11] A.P. Kasih, "Survei UNICEF: 66 Persen Siswa Mengaku Tak Nyaman Belajar di Rumah," 2020. [Online] Retrieved from: https://edukasi.kompas.com/read/2020/06/24/090832371/survei-unicef66-persen-siswa-mengaku-tak-nyaman-belajar-di-rumah.

[12] Sagala and Syaiful, Konsep dan Makna Pembelajaran Untuk Membantu Memecahkan Problematika Belajar dan Mengajar. Bandung: Alfabeta 2011

[13] L.W. Anderson and D.R. Krathwohl, Kerangka landasan untuk pembelajaran, pengajaran, dan asesmen (terjemahan Agung Prihantoro). New York: Addition Wesley Longman.(buku asli diterbitkan tahun 2001), 2010. 